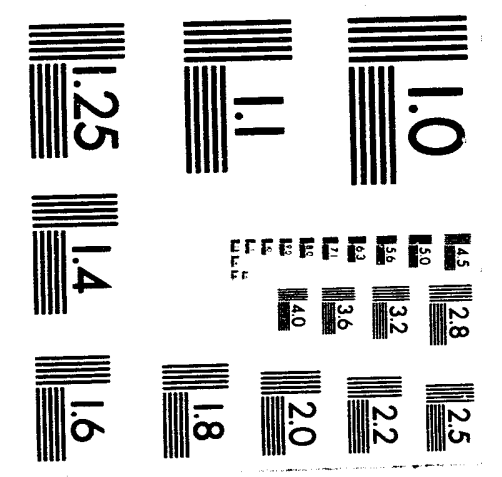



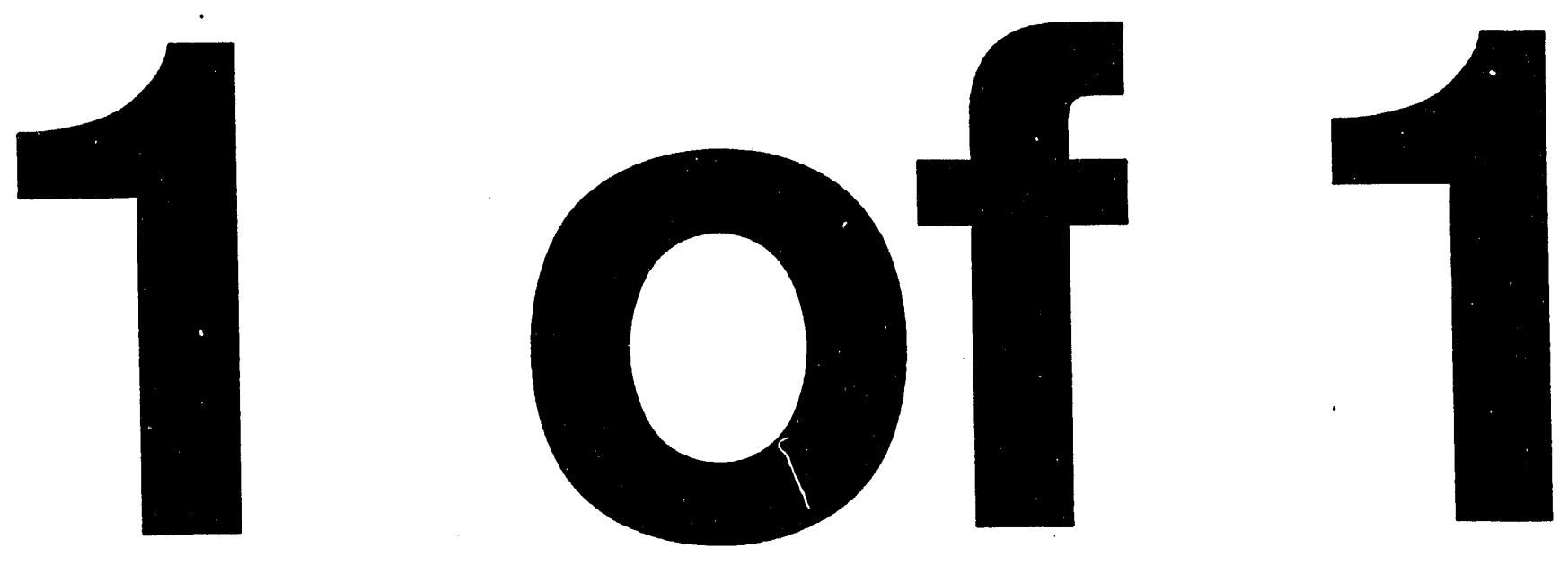


\title{
THERMOCHEMICAL DATA FOR CVD MODELING FROM AB INITIO CALCULATIONS
}

\author{
PAULINE HO* AND CARL F. MELIUS** \\ * Sandia National Laboratories, Albuquerque, NM 87185-0601 \\ **Sandia National Laboratories, Livermore, CA 94551-0969
}

\begin{abstract}
$A b$ initio electronic-structure calculations are combined with empirical bond-additivity corrections to yield thermochemical properties of gas-phase molecules. A self-consistent set of heats of formation for molecules in the Si-H, Si-H-Cl, Si-H-F, Si-N-H and Si-N$\mathrm{H}-\mathrm{F}$ systems is presented, along with preliminary values for some $\mathrm{Si}-\mathrm{O}-\mathrm{C}-\mathrm{H}$ species.
\end{abstract}

\section{INTRODUCTION}

Developing a good model for a CVD process generally requires some description of the chemistry occurring in the process, either from an equilibrium or chemical kinetics point of view. Unfortunately, thermochemical data for many CVD systems of interest are often incomplete or inconsistent.

However, quantum chemistry has now reached the point where ab initio electronicstructure calculations yield usable thermochemical information for certain classes of compounds. For a number of years, we have been using the BAC-MP4 method, which combines calculations done at the MP4 level of theory (see next section) with empirical bond-additivity corrections (BACs), to obtain an extensive, self-consistent set of thermochemical data.

This method has been applied to over 2800 species, primarily molecules made up of first-row elements that are relevant to combustion, ${ }^{1}$ but including a number of molecules relevant to the CVD of silicon-containing compounds. In this paper, we first review some of these earlier results before presenting some recent work on $\mathrm{Si}-\mathrm{O}-\mathrm{C}-\mathrm{H}$ compounds. Detailed discussions of the Si-H, Si-H-Cl, Si-H-F, Si-N-H and Si-N-H-F systems are available elsewhere, ${ }^{2-5}$ as well as similar work on $\mathrm{Si}-\mathrm{C}-\mathrm{H}$ and $\mathrm{Si}-\mathrm{C}-\mathrm{Cl}-\mathrm{H}$ that is not included in this paper. ${ }^{6,7}$

\section{THEORETICAL METHODS}

The methods used in this work have been described in the literature, ${ }^{1,4,5}$ so only a short description is included here.

Electronic structure calculations were done using the Gaussian codes. ${ }^{8}$ Equilibrium geometries and harmonic vibrational frequencies were obtained at the $\mathrm{HF} / 6-31 \mathrm{G}^{*}$ level of theory (restricted Hartree-Fock theory, ${ }^{9} \mathrm{RHF}$, for closed shell molecules, and unrestricted Hartree-Fock theory, ${ }^{10}$ UHF, for open shell molecules, using the $6-31 \mathrm{G}^{*}$ basis set ${ }^{11,12}$ ). This level of theory provides sufficiently accurate equilibrium geometries, but does not provide total energies suitable for determining reaction energies involving the breaking of covalent bonds. Vibrational frequencies calculated at this level of theory are known ${ }^{13}$ to be systematically larger than experimental values, so each calculated frequency has been scaled by dividing it by 1.12 (determined by averaging the ratio of calculated to experimental vibrational frequencies over many known

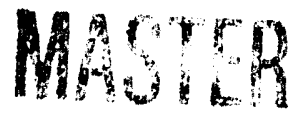


species). To determine atomization enthalpies, the effects of electron correlation were included in the calculation by performing single-point calculations at the $\mathrm{HF} / 6-31 \mathrm{G}^{*}$ geometries using Møller-Plesset (MP) perturbation theory ${ }^{14-16}$ with single, double, triple and quadruple substitutions and the $6-31 \mathrm{G}^{* *}$ basis set. ${ }^{11,12}$ This level of theory is generally a good compromise between the need for chemical accuracy in the calculated energies and limits on molecular size imposed by computational limitations. For most molecules, fourth-order perturbation calculations were done, but this was not possible for larger molecules like TEOS (tetraethoxysilane). In these cases, secondorder perturbation calculations were done, which yields usable atomization enthalpies but with greater uncertainties than the MP4 calculations.

Empirical BACs are used to account for systematic errors in the $a b$ initio calculations which result primarily from basis-set truncation. BACs are determined for each level of perturbation theory and depend mainly on the bond type and bond length, but there are small additional corrections for neighboring atoms. The BACs are obtajned from reference compounds which have well-established experimental heats of formation or from analogous correction parameters for related classes of compounds. For $\mathrm{Si}-\mathrm{H}, \mathrm{Si}-\mathrm{Cl}, \mathrm{Si}-\mathrm{F}$ and $\mathrm{Si}-\mathrm{C}$ bonds, $\mathrm{SiH}_{4}, \mathrm{SiCl}_{4}, \mathrm{SiF}_{4}$ and $\mathrm{Si}\left(\mathrm{CH}_{3}\right)_{3}$ were used as reference compounds, while $\mathrm{Si}_{2} \mathrm{H}_{6}$ was the reference compound for $\mathrm{Si}-\mathrm{Si}$ bonds. For $\mathrm{Si}-\mathrm{N}$ bonds, however, no good reference species was available, so we used parameters similar to those for $\mathrm{Si}-\mathrm{C}$ bonds. For $\mathrm{Si}-\mathrm{O}$ bonds, the $\mathrm{BACs}$ were based on a theoretical value obtained for $\mathrm{H}_{3} \mathrm{SiOH}$ at a higher level of theory ${ }^{17}$ (vide infra). There are additional BAC terms for spin, both for open-shell molecules and for closed-shell molecules which are UHF unstable. These terms are discussed in detail elsewhere. ${ }^{1,4,5}$ The sum of the BAC terms are combined with the electronic energy from the perturbation theory calculation and the zero-point energy to obtain the heat of formation at $0 \mathrm{~K}$. Statistical-mechanics equations involving the calculated geometries and scaled frequencies are then used to determine entropies, heat capacities, enthalpies, and free energies at other temperatures. ${ }^{1}$

The error estimates given in the tables are determined via a systematic, but ad hoc, procedure using the results from electronic structure calculations at lower levels of theory. ${ }^{1,4}$ These uncertainties only reflect the applicability of the calculational methods to the various species. As discussed in more detail elsewhere, ${ }^{3,4}$ the actual uncertainties may be somewhat larger for species for which we do not have good reference species, for example molecules with $\mathrm{Si}-\mathrm{N}$ or $\mathrm{Si}-\mathrm{O}$ bonds or with short $\mathrm{Si}-\mathrm{Si}$ (multiple) bonds. In the case of the larger molecules that were only studied at the MP2 level of theory, we have not developed a method for systematically estimating errors, but consider the uncertainties in the heats of formation to be in the range of $5-7 \mathrm{kcal} / \mathrm{mole}$.

\section{RESULTS AND DISCUSSION}

Tables I and II list our calculated heats of formation and entropies at $298 \mathrm{~K}$ for molecules in the Si-H, Si-H-Cl, Si-H-F, Si-N-H and Si-N-H-F systems. Detailed information on energies, vibrational frequencies and geometries from the $a b$ initio calculations, can be found in the full papers. ${ }^{2-5}$

There are some general trends observable in the heats of formation. For example, the heats of formation of the $\mathrm{SiH}_{n} \mathrm{Cl}_{(4-n)}, \mathrm{SiH}_{n} \mathrm{~F}_{(4-n)}$, and $\mathrm{SiH}_{n}\left(\mathrm{NH}_{2}\right)_{(4-n)}(0 \leq$ $n \leq 4)$ species show nearly linear dependences on $n$, indicating that the successive replacement of $\mathrm{Si}-\mathrm{H}$ bonds with $\mathrm{Si}-\mathrm{Cl}, \mathrm{Si}-\mathrm{F}$ or $\mathrm{Si}-\mathrm{NH}_{2}$ bonds is accompanied by monotonic changes in stabilization. This is also true for the replacement of $\mathrm{Si}-\mathrm{F}$ bonds by $\mathrm{Si}-\mathrm{NH}_{2}$ bonds in the $\mathrm{SiF}_{n}\left(\mathrm{NH}_{2}\right)_{(4-n)}$ species. In contrast, the heats of 
formation for the $\mathrm{SiH}_{n}, \mathrm{SiCl}_{n}, \mathrm{SiF}_{n}, \mathrm{SiH}_{n} \mathrm{NH}_{2}$ and $\mathrm{SiF}_{n} \mathrm{NH}_{2}$ compounds do not vary smoothly with $n$. In addition, the first and third successive $\mathrm{Si}-\mathrm{X}(\mathrm{X}=\mathrm{H}, \mathrm{Cl}, \mathrm{F})$ bond dissociation energies (BDLs) are significantly higher than the second and fourth surcessive BDEs. These observations are manifestations of the change in hybridization of the silicon from $\mathrm{sp}^{3}$ to $\mathrm{s}^{2} \mathrm{p}^{2}$ at $\mathrm{SiX}_{2}$.

Our calculated heats of formation compare favorably with the literature, especially for the saturated species. For example, for the $\mathrm{SiH}_{n} \mathrm{Cl}_{(4-n)}$ and $\mathrm{SiH}_{n} \mathrm{~F}_{(4-n)}$ species, our values agree quite well with those given in the JANAF tables ${ }^{18}$ and by Walsh. ${ }^{19} \mathrm{Our}$ values for $\mathrm{Si}_{3} \mathrm{H}_{8}$ and $\mathrm{Si}_{2} \mathrm{~F}_{6}$ also agree well with those given in the CATCH tables. ${ }^{20}$ For the molecules with $\mathrm{Si}-\mathrm{N}$ bonds, however, virtually no data are available in the literature for comparison with our heats of formation. For $\mathrm{H}_{3} \mathrm{SiNH}_{2}$, Jolly and Bakke ${ }^{21}$ have estimated a heat of formation of $-12 \mathrm{kcal} \mathrm{mol}^{-1}$, which agrees well with our calculated value of $-11.45 \mathrm{kcal} \mathrm{mol}^{-1}$. The literature data for radical species are much sparser. The heat of formation of $\mathrm{SiH}_{2}$ has been the subject of much recent study, ${ }^{22}$ and our current calculated value of $64.8 \mathrm{kcal} \mathrm{mol}^{-1}$ is in good agreement with the value of 65.2 now recommended by Walsh. ${ }^{23}$ For two isomers of $\mathrm{Si}_{2} \mathrm{H}_{4}$, our calculated values for $\mathrm{H}_{3} \mathrm{SiSiH}$ and $\mathrm{H}_{2} \mathrm{Si}=\mathrm{SiH}_{2}$ are $74.9 \mathrm{kcal} \mathrm{mol}^{-1}$ and $62.9 \mathrm{kcal} \mathrm{mol}^{-1}$, respectively, which agree well with the experimental values of $74.6 \pm 2.0$ and $\leq 62.3 \mathrm{kcal} \mathrm{mol}^{-1}$ obtained by Walsh. ${ }^{23}$

In some cases, substantial differences exist in the literature and our results support one value over another. For example, our values of -76.0 and $-237.4 \mathrm{kcal} \mathrm{mol}^{-1}$ for $\mathrm{SiCl}_{3}$ and $\mathrm{SiF}_{3}$, respectively, support the values in the literature of -80 and $-239 \mathrm{kcal} \mathrm{mol}^{-1}$ derived from bond dissociation energy measurements, ${ }^{19}$ rather than the values of -93.3 and $-259.4 \mathrm{kcal} \mathrm{mol}^{-1}$ derived from effusion/mass-spectrometric studies. ${ }^{18}$ There are, of course, other cases in which disagreement between our values and literature values cannot be explained simply, some cases where disagreements may not be significant because the literature values are very uncertain, and many cases where no literature value exists.

We have also applied our calculational methods to a number of transition states that give insight into decomposition mechanisms. For example, several transition states relevant to disilane decomposition are included in Table I. Although disilane decomposes primarily $\mathrm{SiH}_{2}$ and $\mathrm{SiH}_{4}$, it can also form $\mathrm{Si}_{2} \mathrm{H}_{4}+\mathrm{H}_{2}$. Our results indicate that, although $\mathrm{H}_{2} \mathrm{Si}=\mathrm{SiH}_{2}$ has a lower heat of formation than $\mathrm{H}_{3} \mathrm{SiSiH}$, disilane decomposition will initially produce $\mathrm{H}_{3} \mathrm{SiSiH}$ because of the high transition state energy for the $\mathrm{Si}_{2} \mathrm{H}_{6} \rightarrow \mathrm{H}_{2} \mathrm{Si}=\mathrm{SiH}_{2}+\mathrm{H}_{2}$ reaction. $\mathrm{H}_{3} \mathrm{SiSiH}$ then has a low barrier for isomerization to $\mathrm{H}_{2} \mathrm{Si}=\mathrm{SiH}_{2}$. Transition states for the decomposition of silylamine are also included in Table II. In contrast with disilane decomposition, the silylamine decomposition pathway for $\mathrm{H}_{2}$ elimination is significantly lower in energy than the pathway for silylene elimination.

Table. III lists calculated thermochemical parameters for species in the Si-O-CH system. For the smaller species, calculated heats of formation are given for both the BAC-MP4 and BAC-MP2 levels of theory. For the larger molecules, only results from BAC-MP2 calculations are listed. In general, the BAC-MP2 numbers appear to be within a few $\mathrm{kcal} / \mathrm{mole}$ of the BAC-MP4 numbers, with no systematic variations. In several cases, Table III lists heats of formation that were estimated using bond additivity methods because the MP2 calculations have not finished yet. We expect that these estimated values will be within $2-3 \mathrm{kcal} / \mathrm{mole}$ of the BAC-MP2 values.

The heats of formation listed in this table are somewhat preliminary; the BAC for $\mathrm{Si}-\mathrm{O}$ bonds may need refinement. The present correction for $\mathrm{Si}-\mathrm{O}$ bonds was developed 
during work on $\mathrm{Si}-\mathrm{O}-\mathrm{H}$ compounds and is based on a higher level (G2) calculation for $\mathrm{H}_{3} \mathrm{SiOH}{ }^{17}$ There is, however, some literature data for $\mathrm{Si}-\mathrm{O}-\mathrm{C}-\mathrm{H}$ species that may support the use of a different reference compound for the correction. Walsh ${ }^{23}$ lists heats of formation of $-119.5,-281.8$ and $-314.3 \mathrm{kcal} / \mathrm{mole}$ for $\left(\mathrm{CH}_{3}\right)_{3} \mathrm{SiOH}, \mathrm{Si}\left(\mathrm{OCH}_{3}\right)_{4}$, and $\mathrm{Si}\left(\mathrm{OC}_{2} \mathrm{H}_{5}\right)_{4}$, respectively. These values are somewhat less negative than our values, and may warrant an adjustment after calculations are done for species such as TEOS and $\left(\mathrm{CH}_{3}\right)_{3} \mathrm{SiOSi}\left(\mathrm{CH}_{3}\right)_{3}$.

The $\Delta H_{f}^{\circ}$ s in Table III were used to analyze possible TEOS decomposition reactions, shown in Table IV. The first two reactions, involving simple breaking of $\mathrm{Si}-\mathrm{O}$ and $\mathrm{O}-\mathrm{C}$ bonds, are very endothermic $(\geq 100 \mathrm{kcal} / \mathrm{mole})$, and will not be significant under the conditions used for TEOS CVD. The next two reactions, involving the formation of $\mathrm{O}=\mathrm{Si}\left(\mathrm{OC}_{2} \mathrm{H}_{5}\right)_{2}$, are also quite endothermic $(\geq 70 \mathrm{kcal} / \mathrm{mole})$. These reactions are multicenter reactions, and are expected to have substantial kinetic barriers in addition to the endothermicities. These reactions will probably also not be significant under TEOS CVD conditions. The last two reactions, involving the formation of the $\mathrm{HSi}\left(\mathrm{OC}_{2} \mathrm{H}_{5}\right)_{3}$ and $\mathrm{HOSi}\left(\mathrm{OC}_{2} \mathrm{H}_{5}\right)_{3}$ species, have lower endothermicities of 46 and $11 \mathrm{kcal} / \mathrm{mole}$, respectively. These are both 4 -center reactions and are expected to have additional kinetic barriers, but the endothermicities indicate that the last reaction is the most reasonable pathway for TEOS decomposition. To investigate this further, transition states for the elimination of ethylene from $\mathrm{CH}_{3} \mathrm{CH}_{2} \mathrm{OSi}(\mathrm{OH})_{3}$ and $\mathrm{CH}_{3} \mathrm{CH}_{2} \mathrm{OSiH}_{3}$ were studied and the results included in Table III. These calculations confirmed the presence of substantial kinetic barriers. For the $\mathrm{CH}_{3} \mathrm{CH}_{2} \mathrm{OSi}(\mathrm{OH})_{3} \rightarrow \mathrm{C}_{2} \mathrm{H}_{4}+\mathrm{Si}(\mathrm{OH})_{4}$ and $\mathrm{CH}_{3} \mathrm{CH}_{2} \mathrm{OSiH}_{3} \rightarrow \mathrm{C}_{2} \mathrm{H}_{4}+\mathrm{SiH}_{4}$ reactions, the activation energies are 70 and 68 $\mathrm{kcal} / \mathrm{mole}$, respectively, while the endothermicities are $12 \mathrm{kcal} / \mathrm{mole}$. These results are consistent with recent experiments by $\operatorname{lin}$ and coworkers, ${ }^{24}$ who report that $\mathrm{k}=$ $5 \times 10^{13} \exp (-61500 / \mathrm{RT})$ for the gas phase decomposition of TEOS.

\section{CONCLUSION}

The combination of high level $a b$ initio electronic-structure calculations and empirical bond-additivity corrections has proven useful in obtaining thermochemical properties of gas-phase molecules for modeling CVD processes. In some cases, the calculated values help choose between conflicting measurements in the literature; in other cases, the calculated values are the only ones available. In addition to providing information on reaction endo/exothermicities, these calculational methods can also provide energetic and geometric information on transition states. Thus, likely reaction pathways can be identified and evaluated.

The calculational methods described in this paper can generally be applied to compounds comprised of elements in the first three rows of the periodic table and are limited to molecules with a relatively small number of heavy atoms. This is primarily caused by computational requirements that scale with higher powers of the number of atoms. The results for the smaller molecules, can, however, be used to develop bondadditivity methods for reliably estimating the thermochemistry of larger gas-phase species and possibly surface species. These types of calculations are also limited by the need for a reference species for each bond type. For many CVD systems, particularly MOCVD systems, good experimental data are sparse enough that we have to resort to estimates based on analogous species, leading to larger uncertainties in the calculated values. 


\section{ACKNOWLEDGMENTS}

We acknowledge the contributions of M. E. Coltrin and J. S. Binkley to the work on the Si-H and $\mathrm{Si}-\mathrm{H}-\mathrm{Cl}$ species, and those of M. C. Lin, M. R. Zachariah and M. D. Allendorf to the work on the $\mathrm{Si}-\mathrm{O}-\mathrm{C}-\mathrm{H}$ species. This work was primarily supported by the U.S. Department of Energy under contract No. DE-AC04-94AL85000, with some support for the work on $\mathrm{Si}-\mathrm{N}-\mathrm{H}-\mathrm{F}$ compounds from DARPA through WRDC/MLBC contract No. F33615-89-C-5628.

\section{REFERENCES}

1. C.F. Melius, "Thermochemistry of Hydrocarbon Intermediates in Combustion: Application of the BAC-MP4 Method", in Springer-Verlag DFVLR Lecture Notes, (Springer Verlag, 1990).

2. P. Ho, M.E. Coltrin, J.S. Binkley and C.F. Melius, J. Phys. Chem. 89, 4647 (1985).

3. P. Ho, M.E. Coltrin, J.S. Binkley and C.F. Melius, J. Phys. Chem. 90, 3399 (1986).

4. P. Ho and C.F. Melius, J. Phys. Chem. 94, 5120 (1990).

5. C.F. Melius and P. Ho, J. Phys. Chem. 95, 1410 (1991).

6. M.D. Allendorf and C.F. Melius, J. Phys. Chem. 96, 428 (1992).

7. M.D. Allendorf and C.F. Melius, J. Phys. Chem. 97, 720 (1993).

8. See, for example, M.J. Frisch, J.S. Binkley, H.B. Schlegel, K. Raghavachari, C.F. Melius, R.L. Martin, J.J.P. Stewart, F.W. Bobrowicz, C.M. Rohlfing, L.R. Kahn, D.J. DeFrees, R. Seeger, R.A. Whiteside, D.J. Fox, E.M. Fluder, S. Topiol, J.A. Pople, Gaussian 86, (Carnegie-Mellon Quantum Chemistry Publishing Unit, Carnegie-Mellon University, Pittsburgh, PA 15213, 1986).

9. C.C. Roothan, J. Rev. Mod. Phys. 23, 69 (1951).

10. J.A. Pople, R.K. Nesbet, J. Chem. Phys. 22, 571 (1954).

11. P.C. Hariharan, J.A. Pople, Theor. Chim. Acta 28, 213 (1973).

12. M.M. Francl, W.J. Pietro, W.J. Hehre, J.S. Binkley, J.A. Pople, J. Chem. Phys. 77, 3654 (1982).

13. J.A. Pople, H.B. Schlegel, R. Krishnan, D.J. DeFrees, J.S. Binkley, M.J. Frisch, R.A. Whiteside, Int. J. Quant. Chem. S15 269 (1981).

14. J.A. Pople, J.S. Binkley, R. Seeger, Int. J. Quantum Chem. S10, 1 (1976).

15. R. Krishnan, J.A. Pople, Int. J. Quantum Chem. 14, 91 (1978).

16. R. Krishnan, M.J. Frisch, J.A. Pople, J. Chem. Phys. 72, 4244 (1980).

17. Michael R. Zachariah, private communication.

18. JANAF Thermochemical Tables, J. Phys. and Chem. Ref. Data 14, Supplement $1(1985)$.

19. R. Walsh, J. Chem. Soc., Faraday Trans. I 79, 2233 (1983).

20. J.B. Pedley, B.S. Iseard, CATCH Tables (University of Sussex, 1972) available from NTIS, Number AD-773468.

21. W.L. Jolly, A.A. Bakke, J. Amer. Chem. Soc. 98, 6500 (1976).

22. See, for example, J.E. Baggott, H.M. Frey, K.D. King, P.D. Lightfoot, R. Walsh, I.M. Watts, J. Phys. Chem. 92, 4025 (1988) and references therein.

23. R. Walsh, in The Chemistry of Organic Silicon Compounds, edited by S. Patai and Z. Rappoport (John Wiley and Sons Ltd., 1989), p. 371.

24. M.C. Lin, private communication; J.C.S. Chu, J. Breslin, N.S. Wang, and M.C. Lin, Mater. Lett. 12, 179 (1991). 
Table I: Calculated Enthalpies $\left(\mathrm{kcal} \mathrm{mol}^{-1}\right.$ ) and Entropies (cal mol-1 $\mathrm{K}^{-1}$ ) for Si-H, $\mathrm{Si}-\mathrm{H}-\mathrm{Cl}$ and $\mathrm{Si}-\mathrm{H}-\mathrm{F}$ Compounds

\begin{tabular}{|c|c|c|}
\hline Species & $\Delta \mathrm{H}_{f}^{\circ}(298)^{a}$ & $S^{\circ}(298)$ \\
\hline $\begin{array}{l}\mathrm{SiH}_{4}{ }^{b} \\
\mathrm{SiH}_{3} \\
\mathrm{SiH}_{2} \\
\mathrm{SiH}\end{array}$ & $\begin{array}{r}8.19 \pm 1.00 \\
47.43 \pm 1.01 \\
64.80 \pm 2.20 \\
91.01 \pm 1.14\end{array}$ & $\begin{array}{l}48.9 \\
51.8 \\
49.5 \\
46.0\end{array}$ \\
\hline $\begin{array}{l}\mathrm{SiCl}_{4}{ }^{b} \\
\mathrm{SiCl}_{3} \\
\mathrm{SiCl}_{2} \\
\mathrm{SiCl}^{2} \mathrm{II}\end{array}$ & $\begin{array}{r}-158.39 \pm 1.00 \\
-76.00 \pm 1.58 \\
-36.15 \pm 3.73 \\
37.76 \pm 2.34\end{array}$ & $\begin{array}{l}79.7 \\
75.6 \\
67.5 \\
55.8\end{array}$ \\
\hline $\begin{array}{l}\mathrm{SiH}_{3} \mathrm{Cl} \\
\mathrm{SiH}_{2} \mathrm{Cl}_{2} \\
\mathrm{SiHCl}_{3}\end{array}$ & $\begin{array}{r}-32.03 \pm 1.06 \\
-74.42 \pm 1.09 \\
-117.14 \pm 1.05\end{array}$ & $\begin{array}{l}60.0 \\
68.8 \\
75.4\end{array}$ \\
\hline $\begin{array}{l}\mathrm{SiH}_{2} \mathrm{Cl} \\
\mathrm{SiHCl}_{2} \\
\mathrm{SiHCl}\end{array}$ & $\begin{array}{c}7.91 \pm 1.13 \\
-33.98 \pm 1.38 \\
15.85 \pm 2.5\end{array}$ & $\begin{array}{l}62.7 \\
71.1 \\
60.1\end{array}$ \\
\hline $\begin{array}{l}\mathrm{Si}_{2} \mathrm{H}_{6}{ }^{b} \\
\mathrm{Si}_{2} \mathrm{H}_{5} \\
\mathrm{H}_{3} \mathrm{SiSiH} \\
\mathrm{H}_{2} \mathrm{Si}=\mathrm{SiH}_{2}\left({ }^{1} \mathrm{~A}_{g}\right) \\
\mathrm{HSiSiH}_{2} \\
\mathrm{Si}\left(\mathrm{H}_{2}\right)_{\mathrm{Si}} \\
\mathrm{Si}\left(\mathrm{H}^{2} \mathrm{Si}\right. \\
\mathrm{Si}_{2}\left({ }^{3} \Sigma_{g}^{-}\right) \\
\mathrm{Si}_{3} \mathrm{H}_{8} \\
\mathrm{TS}^{c} \\
\mathrm{TS}^{c}{ }^{c} \\
\mathrm{TS3}^{c} \\
\mathrm{TS}^{c}\end{array}$ & $\begin{array}{r}19.11 \pm 1.00 \\
55.39 \pm 1.02 \\
74.91 \pm 2.73 \\
62.90 \pm 2.30 \\
102.05 \pm 2.48 \\
95.62 \pm 1.70 \\
118.82 \pm 2.86 \\
145.79 \pm 1.31 \\
28.36 \pm 1.03 \\
87.94 \pm 2.25 \\
104.77 \pm 2.71 \\
70.91 \pm 2.19 \\
66.48 \pm 1.58\end{array}$ & $\begin{array}{l}65.9 \\
70.0 \\
68.0 \\
65.6 \\
66.3 \\
58.8 \\
59.1 \\
54.8 \\
83.9 \\
64.6 \\
69.0 \\
69.1 \\
68.3\end{array}$ \\
\hline $\begin{array}{l}\mathrm{SiF}_{4}{ }^{b} \\
\mathrm{SiF}_{3} \\
\mathrm{SiF}_{2} \\
\mathrm{SiF} \\
\mathrm{SiHF}_{3} \\
\mathrm{SiH}_{2} \mathrm{~F}_{2} \\
\mathrm{SiH}_{3} \mathrm{~F} \\
\mathrm{SiHF}_{2} \\
\mathrm{SiH}_{2} \mathrm{~F} \\
\mathrm{SiHF} \\
\mathrm{Si}_{2} \mathrm{~F}_{6}\end{array}$ & $\begin{array}{r}-385.99 \pm 1.00 \\
-237.42 \pm 1.87 \\
-149.86 \pm 4.00 \\
-12.42 \pm 2.89 \\
-288.63 \pm 1.34 \\
-186.38 \pm 1.47 \\
-85.50 \pm 1.21 \\
-139.57 \pm 1.89 \\
-42.16 \pm 1.37 \\
-35.70 \pm 2.85 \\
-569.62 \pm 3.47\end{array}$ & $\begin{array}{l}68.2 \\
67.8 \\
61.4 \\
52.7 \\
66.6 \\
62.8 \\
57.0 \\
65.1 \\
59.7 \\
57.1 \\
97.2\end{array}$ \\
\hline
\end{tabular}

a See text for discussion of error estimates.

$b$ Reference compound

c Transition states for the 1) $\mathrm{H}_{3} \mathrm{SiSiH} \rightarrow \mathrm{H}_{2} \mathrm{Si}=\mathrm{SiH}_{2}$ isomerization, 2) $\mathrm{Si}_{2} \mathrm{H}_{6} \rightarrow$ $\mathrm{H}_{2} \mathrm{Si}=\mathrm{SiH}_{2}+\mathrm{H}_{2}$ reaction, 3) $\mathrm{Si}_{2} \mathrm{H}_{6} \rightarrow \mathrm{H}_{3} \mathrm{Si}=\mathrm{SiH}+\mathrm{H}_{2}$ reaction, and 4) $\mathrm{Si}_{2} \mathrm{HI}_{6} \rightarrow$ $\mathrm{SiH}_{2}+\mathrm{SiH}_{4}$ reaction. 
Table II. Calculated Enthalpies $\left(\mathrm{kcal} \mathrm{mol}^{-1}\right)$ and Entropies $\left(\mathrm{cal} \mathrm{mol}^{-1} \mathrm{~K}^{-1}\right.$ ) for Si-N-H and $\mathrm{Si}-\mathrm{N}-\mathrm{H}-\mathrm{F}$ Compounds

\begin{tabular}{|c|c|c|}
\hline Species & $\Delta \mathrm{H}_{f}^{\circ}(298)^{a}$ & $S^{\circ}(298)$ \\
\hline 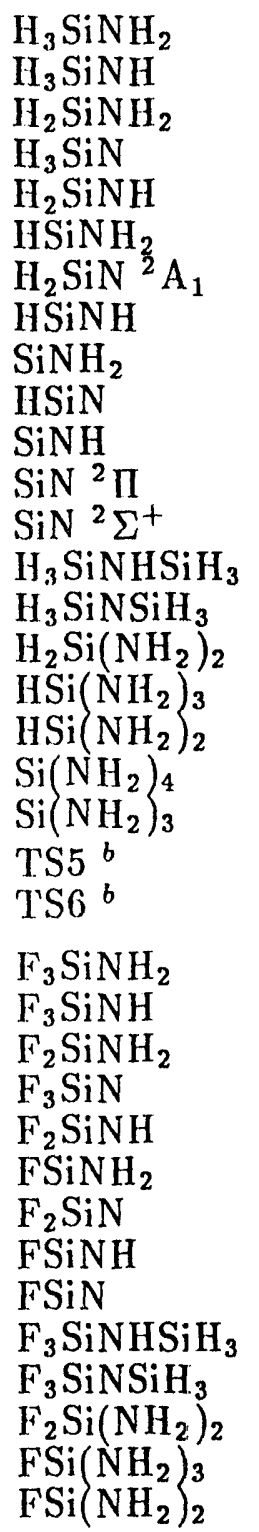 & $\begin{array}{r}-11.45 \pm 1.47 \\
51.32 \pm 1.38 \\
28.03 \pm 1.26 \\
96.56 \pm 1.31 \\
40.99 \pm 3.26 \\
26.33 \pm 1.62 \\
141.40 \pm 4.40 \\
84.80 \pm 4.96 \\
48.67 \pm 1.55 \\
92.98 \pm 24.3 \\
38.39 \pm 5.41 \\
130.72 \pm 5.67 \\
115.55 \pm 8.85 \\
-14.32 \pm 2.03 \\
48.90 \pm 2.49 \\
-37.30 \pm 2.65 \\
-64.86 \pm 3.80 \\
5.62 \pm 2.23 \\
-92.88 \pm 5.15 \\
-18.77 \pm 3.21 \\
62.67 \pm 3.45 \\
51.72 \pm 1.18 \\
-317.89 \pm 2.93 \\
-249.65 \pm 2.21 \\
-167.24 \pm 1.48 \\
-200.02 \pm 1.59 \\
-146.94 \pm 1.38 \\
-80.01 \pm 1.92 \\
-63.11 \pm 3.47 \\
-13.57 \pm 2.63 \\
54.37 \pm 8.57 \\
-320.19 \pm 3.16 \\
-252.84 \pm 3.80 \\
-247.30 \pm 4.52 \\
-170.70 \pm 5.19 \\
-95.47 \pm 2.54\end{array}$ & $\begin{array}{l}65.7 \\
65.5 \\
65.8 \\
59.5 \\
59.9 \\
59.8 \\
57.2 \\
60.6 \\
58.6 \\
54.8 \\
51.7 \\
52.3 \\
52.0 \\
83.5 \\
83.7 \\
74.4 \\
82.8 \\
75.3 \\
90.0 \\
84.3 \\
62.8 \\
64.3 \\
80.0 \\
82.2 \\
77.2 \\
73.9 \\
70.9 \\
65.8 \\
70.5 \\
68.9 \\
63.7 \\
96.0 \\
97.6 \\
82.8 \\
88.0 \\
79.7\end{array}$ \\
\hline
\end{tabular}

a See text for discussion of error estimates.

${ }_{b}$ Transition states for the 5) $\mathrm{H}_{3} \mathrm{SiNH}_{2} \rightarrow \mathrm{SiH}_{2}+\mathrm{NH}_{3}$, and 6) $\mathrm{H}_{3} \mathrm{SiNH}_{2} \rightarrow \mathrm{HSiNH}_{2}$ $+\mathrm{H}_{2}$ reactions. 
Table III. Preliminary Values for $\Delta \mathrm{H}_{f}^{\circ}(298)$ at Two Levels of Theory (kcal mol ${ }^{-1}$ ) and Entropies (cal mol-1 $\mathrm{K}^{-1}$ ) for Some Si-O-C-H Compounds

\begin{tabular}{|c|c|c|c|c|}
\hline \multirow[t]{2}{*}{ Species } & \multicolumn{2}{|c|}{$\Delta \mathrm{H}_{f}^{\circ}(298)^{a}$} & \multirow[t]{2}{*}{$S^{\circ}(298)$} & \\
\hline & BAC-MP4 & BAC-MP2 & & \\
\hline $\begin{array}{l}\mathrm{Si}\left(\mathrm{OCH}_{3}\right)_{4} \\
\mathrm{Si}(\mathrm{OH})\left(\mathrm{OCH}_{3}\right)_{3} \\
\mathrm{Si}(\mathrm{OCH})_{2}(\mathrm{OH})_{2} \\
\mathrm{SiOH}\left(\mathrm{OCH}_{3}\right)_{2} \\
\mathrm{O}=\mathrm{Si}\left(\mathrm{OCH}_{3}\right)_{2}\end{array}$ & $\begin{array}{l}-304.8 \pm 6.5 \\
-172.3 \pm 2.2 \\
-174.9 \pm 8.4\end{array}$ & $\begin{array}{l}-285.5 \\
-294.8 \\
-302.5 \\
-172.7 \\
-174.0\end{array}$ & $\begin{array}{r}123.2 \\
113.2 \\
103.9 \\
98.3 \\
92.3\end{array}$ & \\
\hline $\begin{array}{l}\mathrm{CH}_{3} \mathrm{OSi}(\mathrm{OH})_{3} \\
\mathrm{Si}(\mathrm{OH})_{2} \mathrm{OCH}_{3} \\
\mathrm{O}=\mathrm{SiOHOCH}_{3} \\
\mathrm{CH}_{3} \mathrm{OSi}(\mathrm{OH})_{2} \mathrm{O} \\
\mathrm{CH}_{2} \mathrm{OSi}(\mathrm{OH})_{3}\end{array}$ & $\begin{array}{l}-316.0 \pm 6.0 \\
-180.9 \pm 1.8 \\
-184.1 \pm 8.0 \\
-242.3 \pm 5.9 \\
-270.1 \pm 6.7\end{array}$ & $\begin{array}{l}-314.2 \\
-181.9 \\
-183.6 \\
-239.1 \\
-268.5\end{array}$ & $\begin{array}{l}91.9 \\
88.2 \\
81.3 \\
92.8 \\
92.1\end{array}$ & \\
\hline $\begin{array}{l}\mathrm{Si}\left(\mathrm{OC}_{2} \mathrm{H}_{5}\right)_{4} \\
\mathrm{Si}(\mathrm{OH})\left(\mathrm{OC}_{2} \mathrm{H}_{5}\right)_{3} \\
\mathrm{Si}(\mathrm{OH})_{2}\left(\mathrm{OC}_{2} \mathrm{H}_{5}\right)_{2} \\
\mathrm{CH}_{3} \mathrm{CH}_{2} \mathrm{OSi}(\mathrm{OH})_{3}\end{array}$ & $-324.6 \pm 5.7$ & $\begin{array}{l}-320.0^{c} \\
-321.0^{c} \\
-321.9 \\
-322.8\end{array}$ & $\begin{array}{r}137.1 \\
117.5 \\
99.0\end{array}$ & \\
\hline $\begin{array}{l}\mathrm{CH}_{3} \mathrm{CH}_{2} \mathrm{OSiH}_{3} \\
\mathrm{HSi}\left(\mathrm{OC}_{2} \mathrm{H}_{5}\right)_{3} \\
\left(\mathrm{CH}_{3}\right)_{3} \mathrm{SiOH} \\
\mathrm{TS7}^{b} \\
\mathrm{TS}^{b}\end{array}$ & $\begin{array}{r}-67.5 \pm 1.1 \\
-121.1 \pm 1.1 \\
-254.2 \pm 3.1 \\
1.0 \pm 7.1\end{array}$ & $\begin{array}{r}-67.8 \\
-235.0 \\
-121.2 \\
-252.8 \\
1.4\end{array}$ & $\begin{array}{r}79.9 \\
132.4 \\
90.9 \\
101.5 \\
84.5\end{array}$ & + \\
\hline $\begin{array}{l}\mathrm{Si}\left(\mathrm{OC}_{2} \mathrm{H}_{5}\right)_{3} \\
\mathrm{OSi}\left(\mathrm{OC}_{2} \mathrm{H}_{5}\right)_{3} \\
\mathrm{O}=\mathrm{Si}\left(\mathrm{OC}_{2} \mathrm{H}_{5}\right)_{2}\end{array}$ & & $\begin{array}{l}-187.0^{c} \\
-248.8^{c} \\
-189.1^{c}\end{array}$ & & \\
\hline $\begin{array}{l}\mathrm{Si}(\mathrm{OH})_{4} \\
\mathrm{SiH}(\mathrm{OH})_{3} \\
\mathrm{SiH}_{2}(\mathrm{OH})_{2} \\
\mathrm{H}_{3} \mathrm{SiOH} \\
\mathrm{Si}(\mathrm{OH})_{3} \\
\mathrm{OSi}(\mathrm{OH})_{3} \\
\mathrm{O}=\mathrm{Si}(\mathrm{OH})_{2} \\
\mathrm{SiO}\end{array}$ & $\begin{array}{r}-325.2 \pm 5.6 \\
-238.4 \pm 2.8 \\
-152.0 \pm 1.2 \\
-67.5 \pm 1.0 \\
-189.9 \pm 1.6 \\
-251.6 \pm 5.4 \\
-192.1 \pm 7.4 \\
-25.0 \pm 4.0\end{array}$ & $\begin{array}{r}-323.9 \\
-238.7 \\
-153.0 \\
-68.4 \\
-191.4 \\
-248.9 \\
-192.0 \\
-23.3\end{array}$ & $\begin{array}{l}81.9 \\
76.4 \\
68.7 \\
61.8 \\
77.6 \\
82.0 \\
70.0 \\
50.5\end{array}$ & \\
\hline
\end{tabular}

a See text for discussion of error estimates.

6 Transition states for the 7) $\mathrm{CH}_{3} \mathrm{CH}_{2} \mathrm{OSi}(\mathrm{OH})_{3} \rightarrow \mathrm{C}_{2} \mathrm{H}_{4}+\mathrm{Si}(\mathrm{OH})_{4}$ and 8) $\mathrm{CH}_{3} \mathrm{CH}_{2} \mathrm{OSiH}_{3} \rightarrow \mathrm{C}_{2} \mathrm{H}_{4}+\mathrm{SiH}_{4}$ reactions.

$c$ Estimated using bond additivity 
Table IV. Thermochemistry for various TEOS decomposition pathways

\begin{tabular}{lll}
\hline & Reaction & $\Delta \mathrm{H}_{r \times n}(298)$ \\
\hline $\mathrm{Si}\left(\mathrm{OC}_{2} \mathrm{H}_{5}\right)_{4}$ & $\longrightarrow \mathrm{Si}\left(\mathrm{OC}_{2} \mathrm{H}_{5}\right)_{3}+\mathrm{OC}_{2} \mathrm{H}_{5}$ & 132 \\
& $\longrightarrow \mathrm{OSi}\left(\mathrm{OC}_{2} \mathrm{H}_{5}\right)_{3}+\mathrm{C}_{2} \mathrm{H}_{5}$ & 100 \\
& $\longrightarrow \mathrm{O}=\mathrm{Si}\left(\mathrm{OC}_{2} \mathrm{H}_{5}\right)_{2}+\mathrm{C}_{2} \mathrm{H}_{4}+\mathrm{C}_{2} \mathrm{H}_{5} \mathrm{OH}$ & 86 \\
& $\longrightarrow \mathrm{O}=\mathrm{Si}\left(\mathrm{OC}_{2} \mathrm{H}_{5}\right)_{2}+\mathrm{O}\left(\mathrm{C}_{2} \mathrm{H}_{5}\right)_{2}$ & 71 \\
& $\left.\longrightarrow \mathrm{HSi}\left(\mathrm{OC}_{2} \mathrm{H}_{5}\right)_{3}+\mathrm{O}=\mathrm{C}_{(} \mathrm{CH}_{3}\right) \mathrm{H}$ & 46 \\
& $\longrightarrow \mathrm{HOSi}\left(\mathrm{OC}_{2} \mathrm{H}_{5}\right)_{3}+\mathrm{C}_{2} \mathrm{H}_{4}$ & 11 \\
\hline
\end{tabular}

\section{DISCLAIMER}

This report was prepared as an account of work sponsored by an agency of the United States Government. Neither the United States Government nor any agency thereof, nor any of their employees, makes any warranty, express or implied, or assumes any legal liability or responsibility for the accuracy, completeness, or usefulness of any information, apparatus, product, or process disclosed, or represents that its use would not infringe privately owned rights. Reference herein to any specific commercial product, process, or service by trade name, trademark, manufacturer, or otherwise does not necessarily constitute or imply its endorsement, recommendation, or favoring by the United States Government or any agency thereof. The views and opinions of authors expressed herein do not necessarily state or reflect those of the United States Government or any agency thereof. 

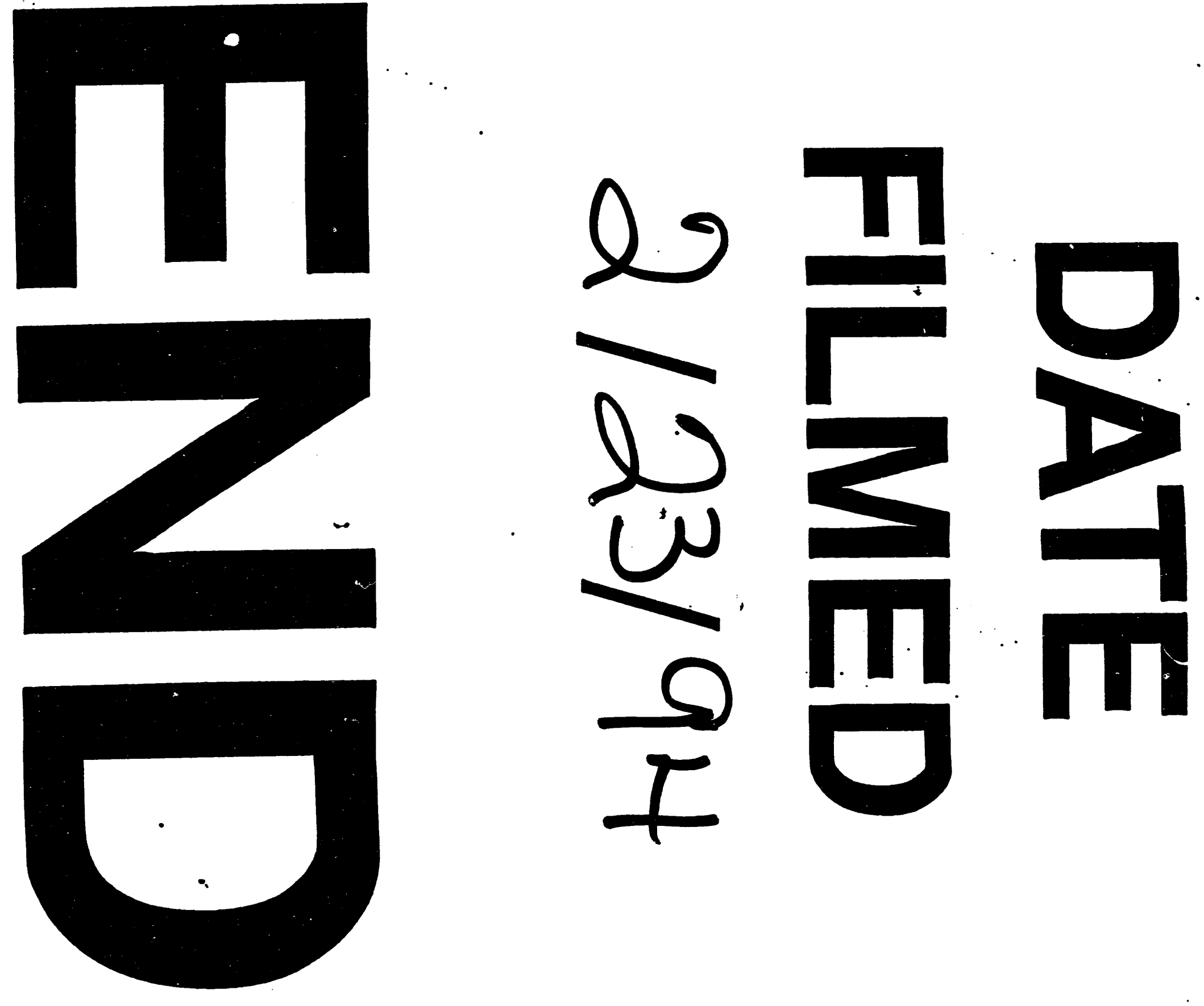


$$
\longrightarrow
$$

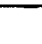

